A. Yakimov, L. Bovnegra, V. Tonkonogyi, V. Vaysman, V. Strelbitskyi, I. Sinko, Odessa, Ukraine

\title{
INFLUENCE OF THE GEOMETRIC CHARACTERISTICS OF THE DISCONTINUOUS PROFILE WORKING SURFACES OF ABRASIVE WHEELS FOR PRECISION AND TEMPERATURE WHEN GRINDING
}

\begin{abstract}
Grinding is the most common finishing method for hardened steel parts. Grinding is accompanied by a large heat release in the cutting area, under the influence of which structural changes appear in the thin surface of the processed parts, tensile stress and even microcracks, which significantly reduce the operational reliability of machines that include these parts. The use of abrasive wheels with an intermittent working surface makes it possible to reduce the temperature in the area of contact of abrasive grains with the material of the workpiece and, as a consequence, stabilize the quality of the surface layer of the workpieces. High-frequency vibrations in the elastic system of the machine, accompanying the work of an intermittent wheel, are a positive factor that reduces the energy consumption of the grinding process. However, under certain conditions of dynamic interaction of the tool with the workpiece, parametric resonance may occur, which worsens the geometric and physicalmechanical parameters of the quality of the surface layer of the processed part. The aim of the work is to realize the possibility of predicting the quality parameters of the surface layer of parts during intermittent grinding by studying the influence of the design features of the macrotopography of the working surface of abrasive wheels and processing modes on the nature of the dynamic interaction of the tool with the workpiece and the heat stress in the cutting area. It was found that the parametric vibrations of the elastic system of the machine tool can be shifted to a more stable area, due to an increase in the number of interruptions of the working surface of the abrasive wheel with a constant ratio of the length of the protrusions and depressions. The increase in the number of breaks on the wheel also contributes to a decrease in temperature in the cutting area. It was found that to maintain the stable operation of the elastic system of the machine, it is necessary to reduce the number of cavities on the grinding wheel with an increase in the cutting speed. However, both of these actions are accompanied by an increase in the heat stress of the grinding process. It has been experimentally established that for ordinary (pendulum) grinding, it is possible to achieve an increase in processing productivity by increasing the speed of the longitudinal movement of the table.
\end{abstract}

Keywords: macrotopography of the working surface; surface roughness; degree of tempering; dynamic interaction; processed material.

Grinding is the final method of mechanical restoration. High speeds of rotation of grinding wheels make it possible to ensure, with this method of processing, a high accuracy of shape and roughness of surfaces of parts. One of the disadvantages of grinding is its high heat intensity, which can lead to a decrease in the specified physical and mechanical properties of the machined surfaces and, as a result, to a decrease in the durability of the mechanism. One of the reasons for the increase in the heat intensity of the grinding process is a decrease in the cutting 
ability of the abrasive wheel due to the smoothing of the microrelief of its working surface and the seizure of the processed material with cutting grains. [1,2,3]. The studies $[7,8,9]$ are devoted to the study of the influence of the shape of abrasive grains on the heat intensity of the grinding process. Despite the difficulties associated with ensuring the required physical and mechanical properties of the machined surfaces during grinding operations, this method of processing continues to be widely used in the industry. From works $[10,11]$ it is known that annually consumed 240,000 grinding wheels with a diameter of 200-500 tons, used only for flat grinding operations.

From works $[12,13,14,15]$ it is known that the use of abrasive wheels with an intermittent profile can reduce the temperature in the area of their contact with the processed material by $30 \%$ or more. A decrease in temperature in the area of cuts of the processed material by abrasive grains occurs due to periodic interruption of the cutting process. [16,17] For the same reason, the cutting process is accompanied by high-frequency oscillations, which facilitate the formation of chips, promote periodic sharpening of cutting grains and, as a result, reduce the energy consumption of the grinding process $[18,19,20]$. However, the periodic interruption of the cutting process associated with the presence of cavities on the grinding wheel leads to inconsistency, rigidity of the technological system, which can lead to the appearance of parametric resonance [21, 22]. Parametric oscillations lead to a cyclic change in the cutting temperature (to cyclic burns on the processed surface) and a decrease in the accuracy of the shape of the ground surfaces $[21,22]$. The aim of this work is to study the effect of macrotopography of the working surface of discontinuous-profile wheels and the parameters of processing modes on the dynamics and heat intensity of the grinding process.

Theoretical studies were carried out on the basis of thermal physics of cutting processes and theories of oscillations. Experimental studies were carried out on a $3 \mathrm{G} 71 \mathrm{M}$ flat-grinding machine. As the test samples, we used flat rectangular tiles made of $18 \mathrm{khgt}$ steel, $150 \mathrm{~mm}$ long, $20 \mathrm{~mm}$ wide, and $10 \mathrm{~mm}$ high. Grinding was carried out with three abrasive wheels PP 200 x 20 x 76 24A 40 CM2 7 K5, one of which had a continuous working surface. The working surface of the second wheel had 12 evenly distributed straight-profile depressions, the dimensions of which were half the size of the cutting protrusions. On the working surface of the third wheel, there were 30 depressions with the same ratio of the lengths of the projections and depressions. The study of the surface roughness was carried out using the "Profilometer 296" device.

Calculations were performed according to the following formulas:

$$
\begin{gathered}
|\Phi| \geq(1+\Psi) / 2 \\
\Phi=\left[\sin \mathrm{n}_{1} \cdot \tau_{1} \cdot\left(\mathrm{n}_{1}^{2} \cdot \sin \mathrm{n}_{2} \cdot \tau_{2}-\mathrm{n}_{2}^{2} \cdot \sin \eta\right)-2 \cdot \mathrm{n}_{1} \cdot \mathrm{n}_{2} \cdot \cos \mathrm{n}_{2} \cdot \tau_{1} \cdot \cos \mathrm{n}_{2} \cdot\left(\tau_{1}+\tau_{2}\right)\right] \cdot \frac{1}{\mathrm{R}+\mathrm{B}}
\end{gathered}
$$




$$
\begin{aligned}
& \psi=\mathrm{n}_{1} \cdot \mathrm{n}_{2} \cdot \cos \eta \cdot \frac{1}{\mathrm{R}^{2}+\mathrm{B}} \\
& \eta=2 \cdot \mathrm{n}_{2} \cdot\left(\tau_{1}+\tau_{2}\right) \\
& \mathrm{n}_{1}=\sqrt{\frac{2 \cdot c_{0}+n_{0}}{2 \cdot m^{\prime}}-h^{2}} \\
& \mathrm{n}_{2}=\sqrt{\frac{2 \cdot c_{0}-n_{0}}{2 \cdot m^{\prime}}-h^{2}} \\
& \mathrm{~B}=h \cdot\left(\mathrm{n}_{2}+h \cdot \sin 2 \mathrm{n}_{2} \cdot \tau_{1}\right) \\
& \mathrm{R}=e^{\left(t_{1}+t_{2}\right)} \\
& \mathrm{n}_{0}=\mathrm{C}_{0} \cdot\left(\frac{\mathrm{t}_{1}-\mathrm{t}_{2}}{\mathrm{t}_{f}}\right) \\
& \tau_{1}=1_{1} / \mathrm{W}_{\mathrm{kr}} \\
& \tau_{2}=1_{2} / \mathrm{W}_{\mathrm{kr}} \\
& l_{1}=\frac{2 \cdot \pi \cdot \mathrm{R}_{\mathrm{kr}}}{\mathrm{n} \cdot(1+\mathrm{N})} \\
& 1_{2}=\frac{2 \cdot \pi \cdot \mathrm{R}_{\mathrm{kr}}}{\mathrm{n} \cdot(1+\mathrm{N})} \\
& \mathrm{N}=1_{2} / 1_{1}
\end{aligned}
$$

Where: $\tau_{1}$ - contact time of the abrasive tool with the processed material, $\mathrm{s}$;

$\tau_{2}$ - time during which there is no interaction of the wheel with the workpiece, s;

$l_{1}$ - gap width of the working surface of the abrasive wheel, $\mathrm{m}$;

$1_{2}$ - distance between two adjacent discontinuities, m;

$\mathrm{C}_{0}$ - reduced stiffness of the elastic system of the grinding machine, $\mathrm{kg} / \mathrm{m}$;

$\mathrm{t}_{\mathrm{l}}, \mathrm{t}_{\mathrm{f}}$ - theoretical and actual thickness of the workpiece removal in one pass, $\mathrm{mm}$;

$\mathrm{W}_{\mathrm{kr}}, \mathrm{R}_{\mathrm{kr}}$ - speed ( $\mathrm{m} / \mathrm{s}$ ) and radius $(\mathrm{m})$ of the grinding wheel, respectively;

$\mathrm{n}$ - number of gaps of the same width evenly distributed over the working surface of the abrasive wheel;

$\mathrm{m}^{1}-$ is the reduced mass of the wheel, $(\mathrm{N} * \mathrm{~S} 2) / \mathrm{m}$;

$\mathrm{n}_{0}$ - cutting hardness $\mathrm{kg} / \mathrm{m}$;

$\mathrm{h}$ - is the coefficient of damping of oscillations in time.

The results are shown in the figures 1-2. 


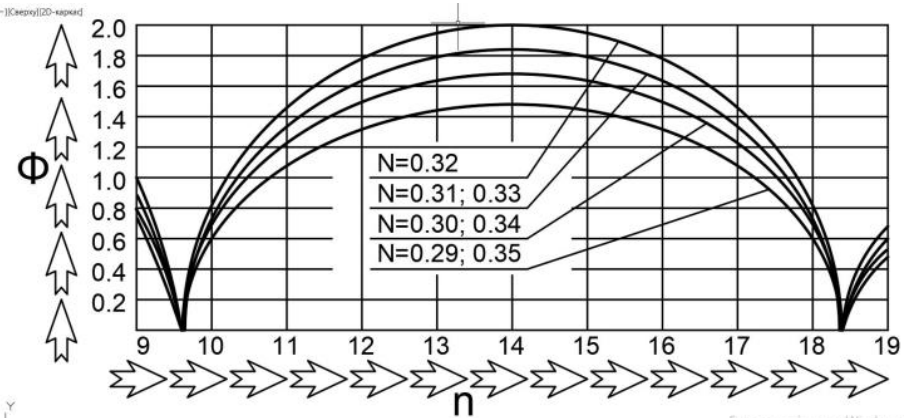

Figure 1 - Dependencies $\Phi=\mathrm{f}(\mathrm{n})$ plotted for different values of $\mathrm{N}$ taken from the interval $0.29 \leq \mathrm{N} \leq 0.35$

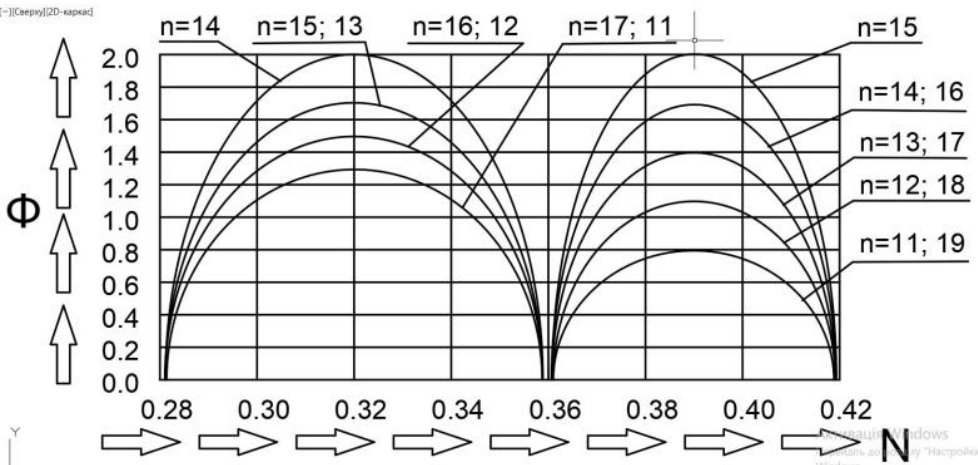

Figure 2 - Dependencies $\Phi=f(N)$, plotted for different values of $n$, taken from the interval $11 \leq \mathrm{n} \leq 19$

Fig. 1,2 shows the dependence of the left side of inequality (1) on the number of depressions on the working surface of the wheel $\mathrm{n}$ and on the coefficient $\mathrm{N}$, which shows how many times the width of the depression differs from the length respectively. It can be seen from fig. 1,2 that the dependence $\Phi=\mathrm{f}(\mathrm{n}, \mathrm{N})$ is a wavy surface. When this surface is cut by planes parallel to the coordinate plane $(\Phi, n)$, semi-ellipses are formed, the major axes of which have the same length, and the sizes of the minor axes depend on the numerical values of the coefficient $\mathrm{N}$. When cutting the surface $\Phi=\mathrm{f}(\mathrm{n}, \mathrm{N})$ by planes parallel to the coordinate plane $(\Phi, N)$, semi-ellipses are formed, the minor axes of which have equal dimensions, and the values of the major axes significantly depend on the number of depressions on the working surface of the discontinuous wheel. 


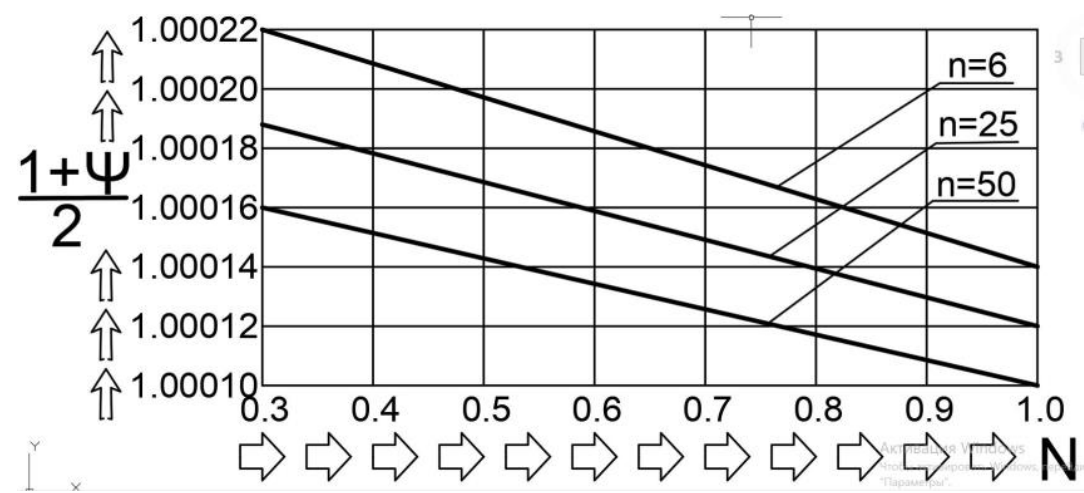

Figure $3-$ Dependencies $(1+\psi) / 2=f(N)$ plotted for different values of $n=6,25,50$

Fig. 3 shows the effect of the geometric parameters of the working surface of the wheel $\mathrm{N}$ and $\mathrm{n}$ on the right-hand side of inequality (1).

Fig. 3 shows that the dependence $(1+\psi) / 2=f(n, N)$ looks like a plane that can be considered parallel to the coordinate plane (n, N). It follows from inequality (1) that the parametric instability of the elastic system of the machine arises when the tops wavy surfaces, described by the graph $\Phi=\mathrm{f}(\mathrm{n}, \mathrm{N})$, protrude above the linear surface described by the graph $(1+\psi) / 2=\mathrm{f}(\mathrm{n}, \mathrm{N})$

Fig. 4 shows the cut line by the plane $(1+\psi) / 2=f(n, N)$ of one of the surface waves $\Phi=\mathrm{f}(\mathrm{n}, \mathrm{N})$.

The cut line looks like an ellipse, the major axis of which is parallel to the $n$ axis, and the small one is parallel to the $\mathrm{N}$ axis.

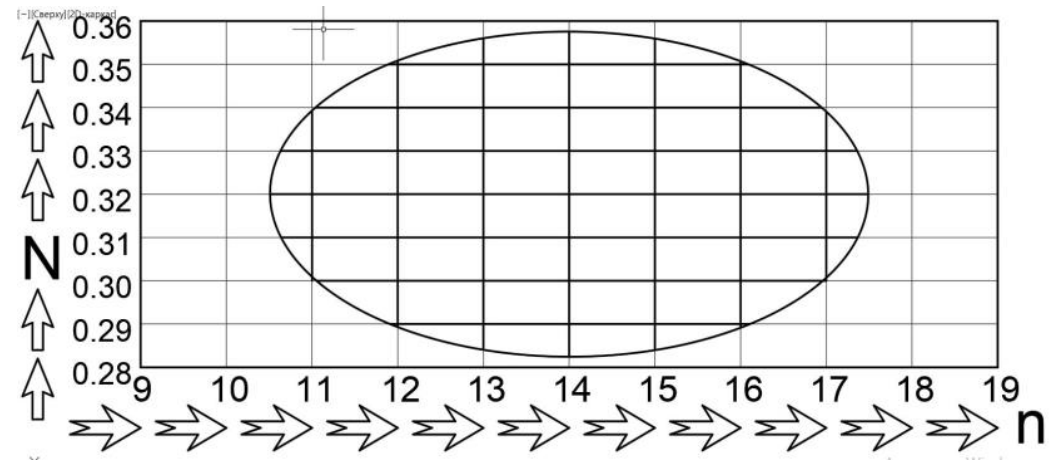

Figure 4 - Line of intersection of a ruled surface $(1+\psi) / 2=f(n, N)$ with a non-ruled surface $\Phi=\mathrm{f}(\mathrm{n} ; \mathrm{N})$ 


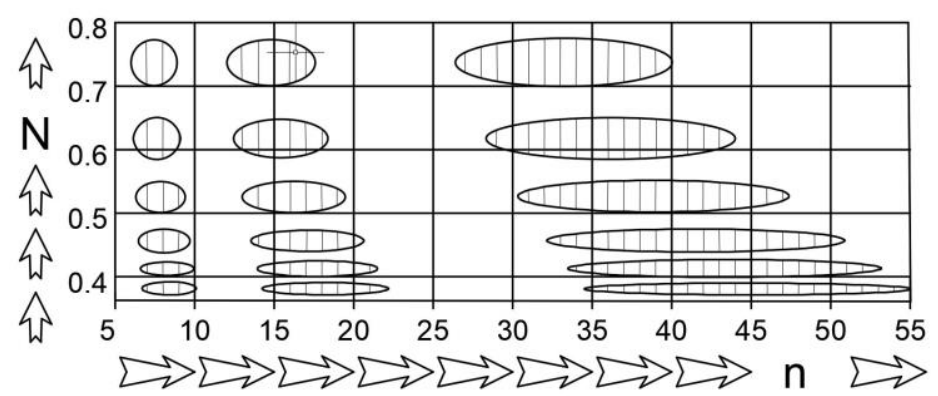

Figure 5 - Ellipse-like lines bounding the regions of parametric instability of the elastic system of the machine

Fig. 5 shows the ellipse-like boundaries of the regions of parametric nonstability of the elastic system of a grinding machine, which represent both lines of intersection of the surface described by the graphs $(1+\psi \square / 2=\mathrm{f}(\mathrm{n}, \mathrm{N})$ (linear flat surface) and $\Phi=\mathrm{f}(\mathrm{n}, \mathrm{N})$ (undulating nonlinear surface).

From analysis of the shape and size of ellipses, built in the coordinate system $(\mathrm{n}, \mathrm{N})$, limited by the intervals $0,35 \leq \mathrm{N} \leq 0,80 ; 5 \leq \mathrm{n} \leq 55$ it is seen:

-with an increase in the number of ruptures (n) of the working surface of an abrasive tool, the areas of unstable operation of the elastic system of the machine are lengthened (the sizes of large axes and ellipses increase; the distance between these areas (areas of stable operation) also increases;

-with an increase in the discontinuity coefficient $\mathrm{N}$, the parametric nonstability area thickens (the size of the small axes of the ellipses increases). In this case, the distance between two adjacent ellipses also increases;

- a decrease in the discontinuity coefficient $\mathrm{N}$ shifts the area of parametric instability in the region of stable operation of the elastic system of the machine in the direction of large values of the breaking numbers of the working surface of the abrasive wheel.

It follows from everything that in order to ensure the stable operation of the elastic system of the machine, it is necessary to increase their number on the wheel when decreasing the size of the cavity in relation to the cutting protrusion.

For example, with $\mathrm{N}=0.73$, stable operation of the elastic system of the machine is provided by two intervals of the number of cutting protrusions: $9 \leq \mathrm{n}$ $\leq 12$ and $18 \leq \mathrm{n} \leq 26$, and with a decrease in the discontinuity coefficient to $\mathrm{N}=$ 0.375 , the intervals of the number of cutting protrusions will change: $10 \leq n \leq 14$ and $22 \leq \mathrm{n} \leq 34$.

From fig 6. it can be seen that an increase in the circumferential speed of the wheel $\mathrm{W}_{\mathrm{kr}}$ leads to a shift in the regions of stable operation of the elastic system of 
the machine (these areas are shaded) in the direction of a decrease in the number of slots on the working surface of the wheel $n$.

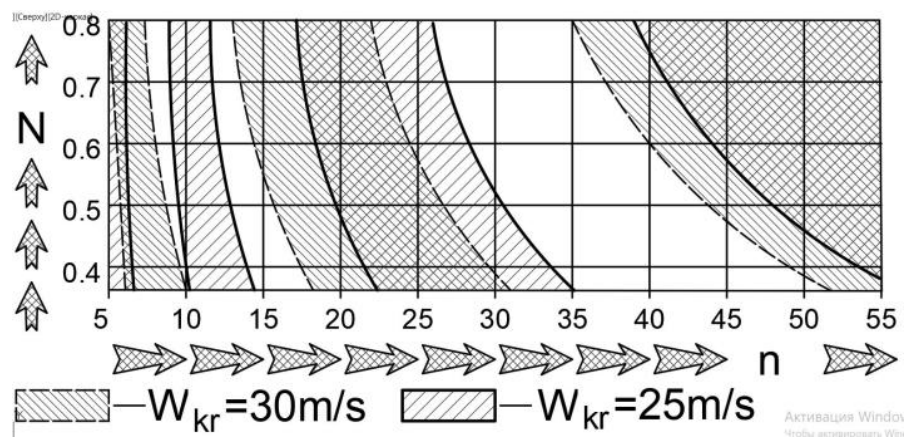

Figure 6 - Displacement of the areas of stable operation of the elastic system of the machine when changing the cutting speed

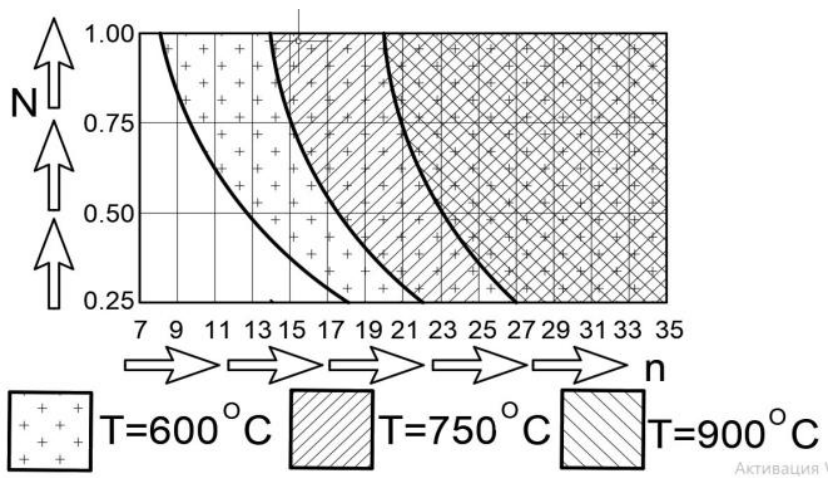

Figure 7 - Displacement of non-cut areas of intermittent grinding when the temperature of continuous grinding changes

Fig 7. three curved lines are shown, each point of which is a set of such geometric parameters of the working surfaces of the abrasive discontinuous wheel, at which the surface temperatures of continuous grinding $\mathrm{T}=600^{\circ} \mathrm{C}, 750^{\circ} \mathrm{C}, 900^{\circ} \mathrm{C}$ decrease to values that do not cause structural and phase transformations. From fig7. it can be seen that the areas of cut-free intermittent grinding with an increase in the temperature of continuous grinding are displaced in the direction of an increase in the number of depressions on the abrasive tool. 
Fig. 8 shows the graphical dependence of the tempering degree of the workpiece surface layer on the longitudinal feed of the table of the surface grinding machine is presented. The degree of tempering was determined by the formula: $N^{\prime}=\left(H_{m}-H_{m}^{\prime}\right) * 100 / H_{m}$, where: $H_{m}$ is the microhardness of the starting material before grinding, $\mathrm{kg} / \mathrm{mm}^{2} ; H_{m}^{\prime}$ - microhardness of the layer lying at a depth of 20$30 \mathrm{mkm}$ after the grinding, $\mathrm{kg} / \mathrm{mn}^{2}$. Samples of steel $12 \times 2 \mathrm{~N} 4 \mathrm{~A}$ were ground without cooling with a continuous wheel 24A $25 \mathrm{CM} 27 \mathrm{~K} 5$ in the following modes: $\mathrm{W}_{\mathrm{kr}}=22 \mathrm{~m} / \mathrm{s} ; \mathrm{t}=0.03 \mathrm{~mm} ; \mathrm{W}_{\mathrm{d}}=3 \mathrm{~m} / \mathrm{min} ; 6 \mathrm{~m} / \mathrm{min} ; 9 \mathrm{~m} / \mathrm{min} ; 12 \mathrm{~m} /$ min $; 15 \mathrm{~m} / \mathrm{min}$. From fig. 8 it can be seen that the degree of tempering of the processed surface decreases with an increase in the longitudinal feed. After grinding flat parts made of $18 \mathrm{KhGT}$ steel with an intermittent wheel, which has 30 cutting projections, and a solid wheel with same characteristics, the roughness heights of the machined surfaces have similar numerical values (fig.9). In other words, as the number of cuts on the discontinuous wheels increases, the surface roughness formed by these wheels approaches the surface roughness obtained by continuous grinding.

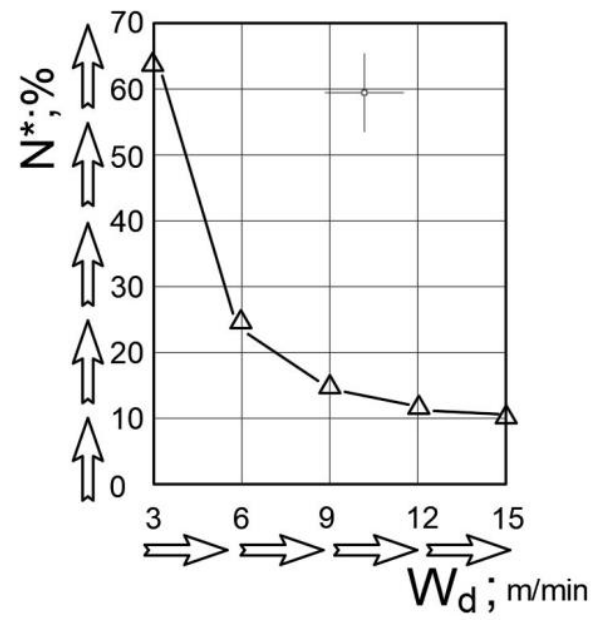

Figure 8-Displacement of non-cut areas of intermittent grinding when the temperature of continuous grinding changes

Fig. 9 shows the experimental dependencies of the roughness parameter $R_{a}$ on the longitudinal feed rate $\mathrm{W}_{\mathrm{d}}$ when grinding flat samples of steel $18 \mathrm{KhGT}$ with solid and two intermittent $(\mathrm{N}=0.5 ; \mathrm{n}=12 ; \mathrm{n}=30)$ wheels $24 \mathrm{~A} 40 \mathrm{CM} 27 \mathrm{~K} 5$ at modes: $\mathrm{W}_{\mathrm{kr}}=30 \mathrm{~m} / \mathrm{st}=0.025 \mathrm{~mm} ; \mathrm{W}_{\mathrm{d}}=3 \mathrm{~m} / \mathrm{min} ; 6 \mathrm{~m} / \mathrm{min} ; 9 \mathrm{~m} / \mathrm{min} ; 12 \mathrm{~m} / \mathrm{min} ; 15 \mathrm{~m} /$ min, without cooling. 


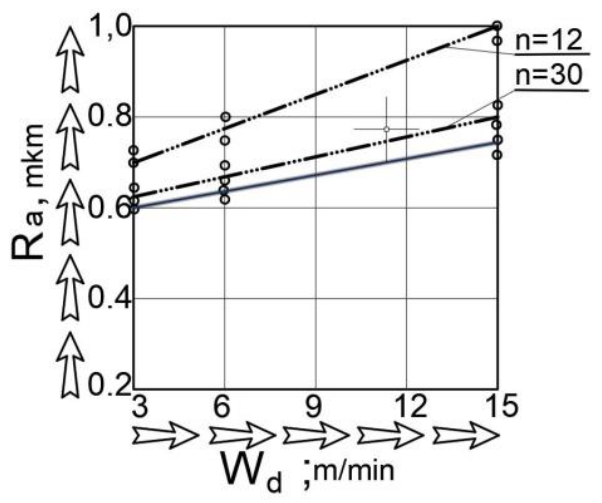

Figure 9 - Dependence of the roughness height of the processed surface on the longitudinal feed rate when grinding with a solid wheel (continuous line) and broken wheels (dash-dot lines)

From fig 9 it can be seen that an increase in the speed of the longitudinal movement of the table of the grinding machine surface leads to an increase in the roughness height of the machined surface. Moreover, the surface formed during grinding with a continuous wheel has a lower roughness in comparison with the surfaces processed by intermittent wheels. With an increase in the number of cutting protrusions on the wheel, the roughness parameter $R_{a}$ decreases.

After grinding flat parts made of $18 \mathrm{KhGT}$ steel, an intermittent wheel with 30 cutting projections and a continuous wheel of the same characteristics of the roughness heights of the machined surfaces have similar numerical values (Fig. 9). In other words, as the number of cuts on the discontinuous wheels increases, the surface roughness formed by these wheels approaches the surface roughness obtained by continuous grinding.

\section{Conclusions.}

1. As a result of the research carried out, it became possible to predict the dynamic and thermal phenomena during intermittent grinding, when changing the operating parameters of the processing of the geometric parameters of the macrotopography of the working surface of abrasive wheels.

2. It was found that in order to maintain the stable operation of the elastic system of the machine, it is necessary, with an increase in the cutting speed, to reduce the number of depressions on the grinding wheel. However, both of these actions are accompanied by an increase in the heat stress of the grinding process. It has been experimentally established that for ordinary (pendulum) grinding, it is possible to achieve an increase in processing productivity by increasing the speed of the longitudinal movement of the table. 
3. It was found that the parametric vibrations of the elastic system of the machine tool can be shifted to a more stable area by increasing the number of interruptions of the working surface of the abrasive wheel, with a constant ratio of the length of the protrusions and depressions. The increase in the number of breaks on the wheel also contributes to a decrease in temperature in the cutting area.

References: 1. Anderson D., Warkentin A., Bauer R. Comparison of spherical and truncated cone geometries for single abrasive- grain cutting. Journal of Materials Processing Technology. vol. 212, i. 9, pp.1946-1953 (2012). 2. Aurich J.C., Kirsch B. Kinematic simulation of high performance grinding for analysis of chip parameters of single grains. CIRP Journal of Manufacturing Science and Technology. vol. 5, pp. 164-174 (2012). 3. Jiang J.l., Ge P.Q., Bi W.B., Zhang L., Wang D.X., Zhang Y. 2D/3D Ground Surface Topography Modeling Considering Dressing and Wear Effects in Grinding Process. International Journal of Machine Tools and Manufacture. vol.74, pp. 29-40 (2013). 4. Li Jia-Jie, Yan $R u$-zhong. Zuhe jichuang yu zidonghua jiagong jishu- Modul. Mach. Tool and Autom. Manuf. Techn, no. 6, pp. 92-95 (2012). 5. Liu Yun-feng, Zhao Hong, Jing Jun-tao, Wei Shi-liang. Jinganshi yu moliaomoju gongcheng - Diamond and abrasives eng..32, no. 4, pp. 55-59 (2012). 6. Marinescu I.D., Rowe B., Dimitrov B., Ohmori H. Tribology of abrasive machining process. William Andrew Publishing. 600 p (2012). 7. Raphael Holtermann, Sebastian Schumann. Modelling, Simulation and experimental investigation of chip formation in internal traverse grinding. Production Engineering Research and Development. vol. 7, i. 2, pp. 251-263 (2013). 8. Xie J., Wei F., Zheng J. H., Tamaki J., Kubo A. 3D laser investigation on micron - scale grain protrusion topography of truncated diamond grinding performance. International Journal of Machine Tools and Manufacture. vol. 51, i. 5, pp. 411419 (2011). 9. Yan Lan, Jiang Feng, Rong Yiming. The research of grinding. Jixie gongcheng xuebao J. Mech. Eng. 48, no. 11, pp. 172-182 (2012). 10. Narasimha M. Improving Cutting Tool Life a Review/M. Narasimha, K. Sridhar, et al.// International Journal of Engineering Research and Development. - vol. 7, Iss.1, pp. 67-75 (2013). 11. Handbook of Machining with Grinding Wheels, Second Edition/ Ioan D. Marinescu, Mike P. Hitchiner. CRC Press. - 750 p (2016). 12. W. Brian Rowe. Principles of modern grinding technology. Jordan Hill, Oxford OX2 8DP: UK. - 421 p. (2011). 13. Bogutsky, $V$. Calculating the profile of intermittent grinding wheel for the sharpening teeth of the broach/ Yu. Novoselov, L Shron // MATEC Web of Conferences 224,01003 (2018) ICMTMTE 2018. DOI:https:// doi. org/10.1051/ matec- conf/ 201822401003. 14. Yaroslavtsev V.M. Otsenka effektivnosti preryivistogo rezaniya na osnove ispolzovaniya zakonomernostey izmeneniya teplonapryazhennosti protsessa/ V.M. Yaroslavtsev, N.G. Nazarov// Nauka i obrazovanie: nauchnoe izdanie MGTU im. N.E. Baumana. - 10 oktyabrya. - pp. 35-42 (2013). DOI:10. 7463/1013. 0623113. 15. Lischenko N.V. Opredelenie temperaturyi preryivistogo shlifovaniya IN.V. Lischenko, V.P. Larshin, A.V. Yakimov//PratsI Odeskogo polItehnIchnogo unIversitetu. - Vip.2 (39), pp. 80-85 (2012). 16. Bogutskiy V.B. O tselesoobraznosti primeneniya shlifovalnyih krugov s preryivistyim profilem na operatsiyah ploskogo shlifovaniya/ V.B. Bogutskiy, Shron L.B.// Progressivnyie tehnologii i sistemyi mashinostroeniya.- №2 (65), pp. 10-15 (2019). 17. Bogutskiy V.B. Analiz konstruktivnyih osobennostey shlifovalnyih krugov s preryivistoy poverhnostyu/ V.B.Bogutskiy, L.B. Shron, B.V. Bogutskiy, B.L. Shron//Uchenyie zapiski Kryimskogo inzhenerno-pedagogicheskogo universiteta.№35.-S.60-64 (2012). 18. Rodriguez Rafael Lemes, Lopes Jose Claudio, Garcia Mateus Vinicius, Tarrento Gilson Eduardo, Rodriguec Alessandro Roger, Luiz Eduardo de Angelo Sanchez, Hamilton Jose de Mello, Paulo Roberto de Aguiar, Eduardo Carlos Bianchi. Grinding process applied to workpieces with different geometries interrupted using CBN wheel. The international Journal of Advanced Manufacturing Technology.107, is. 3, pp. 1265-1275 (2020). DOI:10.1007/S 00170-02005122-2. 19. Tawakoli,T., Azarhoushang, B. The oretical and experimental investigation of intermittent grinding of SiC with a segmented grinding wheel. Int J Abras Technol. 4 (1), pp. 90-99 (2011). https://doi. org/10.1504/IJAT.2011. 039005. 20. Fang C.,Xu,X. Analysis of temperature distributions in surface grinding with intermittent wheels. The International Journal of Advanced Manufacturing 
Technology. 71, pp. 23-31 (2014). https://doi.org/10.1007/S 00170013-5472-1. 21. Oborskiy G.A. Obobschenie predstavleniy o dinamicheskoy harakteristike protsessa rezaniya /G.A. Oborskiy, P.A. Linchevskiy,A.A. Orgiyan,R.A. Maschey// PratsI Odeskogo polItehn.unIv-tu. - Vip.1 (38), pp. 66-70 (2012). URI: http:// pratsi.opu.ua/app/webroot/articles/1346754609.pdf. 22. Orgiyan A.A. Intensivnost parametricheskih rezonansov pri preryivistom rezaniy/A.A.Orgiyan, I.M.Tvorischuk // Suchasni tehnologiyi v mshinobuduvanni - Modern technologies in mechanical engineering: 3b. nauk. Pr. Kharkiv: NTU "KhPI". - Vip.9, pp. 124-133 (2014). http://repository.kpi.kharkov.ua/handle/KhPIPress/16865. 23. Nikitin S.P. Influence of technological parameters on the thermodynamic system of cutting equipment/S.P. Nikitin V.K.Zal'taberg//Russian Engineering Research. Vol. 32, №1, pp. 90-92 (2012). 24. Khanov A.M. Elastic and Thermal Dynamic Processes in the Grinding of Thermoprotective Coatings/ A.M Khanov, S.P. Nikitin, L.D Sirotenko. E.O. Trofimov,E.V.Matygullina// Russian Engineering Research. (2015). Vol. 35, №9, pp.708-710.

\title{
Олексій Якімов, Любов Бовнегра, Володимир Тонконогий, Владислав Вайсман, Віктор Стрельбіцький, Інна Сінько, Одеса, Украіна
}

\section{ВПЛИВ ГЕОМЕТРИЧНИХ ХАРАКТЕРИСТИК ПЕРЕРИВЧАСТОГО ПРОФІЛЮ РОБОЧИХ ПОВЕРХОНЬ АБРАЗИВНИХ КРУГІВ НА ТОЧНІСТЬ І ТЕМПЕРАТУРУ ПРИ ШЛІФУВАННІ}

\begin{abstract}
Анотація. Шліфування $\epsilon$ найбільш поширеним методом фінішної обробки деталей із загартованих сталей. Шліфування супроводжується виділенням великої кількості тепла в зоні різання, під дією якого в тонкому поверхневому шарі оброблених деталей виникають структурні зміни, напруження розтягу $i$ навіть мікротріщини, ще істотно знижують експлуатаиійну надійність машин до складу яких входять ичі деталі. Застосування абразивних кругів з переривчастою робочою поверхнею дозволяють знизити температуру в зоні контакту абразивних зерен з матеріалом деталі $i$, як наслідок стабілізувати якість поверхневого шару оброблюваних деталей. Високочастотні коливання в пружній системі верстата, які супроводжують роботу переривчастого круга, $\epsilon$ позитивним чинником, щзо знижує енергоємність прочесу шліфування. Однак, при певних умовах динамічної взаємодії інструменту із заготовкою може виникнути параметричний резонанс, який погіриує геометричні $і$ фізикомеханічні параметри якості поверхневого шару обробленої деталі. Метою роботи є реалізація можливості прогнозування параметрів якості поверхневого шару деталей при переривчастому шліфуванні за рахунок вивчення впливу конструктивних особливостей макротопографіі робочої поверхні абразивних кругів та режимів обробки на характер динамічної взаємодії інструменту $з$ заготівкою і теплонапруженність у зоні різання. Встановлено, що параметричні коливання пружної системи верстата можсна зрушити в більш стійку область за рахунок збільшення кількості переривань робочої поверхні абразивного круга при незмінному співвідношенні протяжності виступів $i$ западин. Збільшення числа розривів у крузі сприяе також зниженню температури в зоні різання. Встановлено, щяо для підтримки стійкої роботи пружної системи верстата необхідно при збільшенні швидкості різання зменшувати число западин на шліфувальному крузі. Однак, обидві иі дії супроводжуються збільшенням теплонапруженості прочесу шліфування. Експериментальним шляхом встановлено, щчо для звичайного (маятникового) шліфування можна домогтися підвищення продуктивності обробки за рахунок збільшення швидкості поздовжнього переміщення робочого столу.
\end{abstract}

Ключові слова: макротопографія робочої поверхні; шорсткість поверхні; ступінь відпущення; динамічна взаємодія; оброблювальний матеріал. 